\title{
EFEKTIVITAS PEMBERIAN SIRUP ZINK DAN MODISCO TERHADAP PERUBAHAN BERAT BADAN PADA BALITA KEKURANGAN ENERGI PROTEIN (KEP) SEDANG DAN BERAT DI WILAYAH KERJA PUSKESMAS JABUNG, JAWA TIMUR
}

\author{
Rifzul Maulina ${ }^{1)}$, Tut Rayani Aksohini Wijayanti ${ }^{2)}$ \\ 1rifzulmaulina3@gmail.com, 2tutrayani@gmail.com \\ ${ }^{1,2}$ Diploma III Kebidanan Poltekkes RS dr Soepraoen Malang, Jln. S. Supriadi No. 22 Malang
}

\begin{abstract}
Abstrak
Kekurangan zat gizi akan menyebabkan simpanan pada tubuh digunakan untuk memenuhi kebutuhan. Seharusnya ini bisa diatasi dengan lebih cepat dengan pemberian kombinasi sirup zink dan modisco Tujuan Penelitian ini adalah untuk melihat efektivitas kombinasi sirup zink dan modisco terhadap perubahan berat badan. Desain penelitian ini menggunakan quasy eksperimen dengan pendekatan pre and post test design with control group. Populasi yang digunakan adalah semua balita yang mengalami kekurangan energi protein sedang dan berat. Sampel dalam penelitian ini sebanyak 20 balita dengan teknik sampling yaitu total sampling. Berdasarkan hasil penelitian setelah dilakukan intervensi selama 2 bulan, sebagian besar mengalami kenaikan berat badan sebanyak 7 orang (70\%) sedangkan pada kelompok kontrol yaitu hanya pemberian modisco setengahnya mengalami kenaikan berat badan sebanyak 5 orang (50\%).Pengumpulan data dalam penelitian ini menggunakan lembar observasi dan data dianalisa menggunakan t-test dengan signifikan $p \leq 0,05$ dan selanjutnya dilakukan uji Eta squared untuk menilai efektivitas. Berdasarkan hasil t-test didapatkan $p=0,034$. Eta Squared yang didapatkan 0,28 disimpulkan terdapat efektivitas yang besar kombinasi pemberian sirup zink dan modisco terhadap peningkatan berat badan balita. Untuk tenaga kesehatan disarankan memberikan kombinasi sirup zink dan modisco untuk mengatasi balita yang kekurangan gizi.
\end{abstract}

Kata Kunci: modisco, perubahan berat badan, zink

\begin{abstract}
Lack of nutrients will cause the body's nutrient stores to be used to needs. This should be overcome more quickly by the combination of zinc and modisco syrup. The purpose of this study was to look at the effectiveness of the combination of zinc and modisco syrup against changes in body weight. The design of this study use quasy eksperimen with the pre and post test design with control group. The population used is all toddlers who having moderate and severe protein energy deficiency. The sample in this study were as many as 20 toddlers with a sampling technique which is total sampling. Based on the results of the study after giving zinc and modisco syrup combinations for 2 month, most of them experienced weight gain as much as 7 people (70\%) in the control group, only modisco administered half had weight gain of 5 people (50\%) Data collection in this study using observation sheets and data were analyzed using $t$-test with significant $p=$ 0.05 and then the Eta squared test was conducted to assess effectiveness. Based on the results of the $t$-test, it was found that $p=0.034$ so that $p<0.05$ which Ha was accepted, it means that there was a difference between zinc and modisco syrup administration to changes in underweight children in infants with moderate and severe. Eta Squared obtained 0.28 concluded that there is a large effectiveness combination of zinc and modisco syrup administration to increase toddler weight. For midwifery are advised to provide a combination of zinc syrup and modisco to treat malnutrition children
\end{abstract}

Keywords: modisco, weight change, zinc

\section{Pendahuluan}

Setiap manusia yang hidup mengalami proses tumbuh kembang, tumbuh berarti berkaitan dengan perubahan ukuran, sedangkan kembang berhubungan dengan aspek deferensiasi bentuk atau fungsi termasuk perubahan emosi dan sosial. Tumbuh kembang 
merupakan proses continue sejak dari konsepsi sampai maturasi atau dewasa yang dipengaruhi oleh faktor bawaan dan lingkungan ${ }^{[1]}$.

Beberapa faktor yang berpengaruh terhadap asupan makanan antara lain kebiasaan makanan, rasa suka dan tidak suka terhadap makanan tertentu akan terbawa sampai dewasa dan seringkali sulit diperbaiki, termasuk juga lingkungan keluarga, media massa, teman sebaya dan penyakit. Problema makan pada anak dapat berakibat buruk bagi tumbuh kembang anak. Sedikitnya makanan yang masuk ke dalam perut anak dapat menjadi indikasi bahwa anak mempunyai peluang besar untuk menderita kurang gizi ${ }^{[2]}$.

Kekurangan zat gizi akan menyebabkan cadangan makanan yang ada di dalam tubuh diambil untuk pemenuhan kebutuhan metabolisme tubuh. Penurunan Jaringan akan terjadi apabila simpanan zat gizi digunakan dalam jangka waktu yang lama.Pada saat terjadi kemerosotan jaringan inilah orang sudah dapt dikatakan malnutrisi dan hal ini biasanya ditandai dengan adanya penurunan berat badan dan perkembangan terhambat ${ }^{[3]}$.

Kekurangan gizi ini dapat diatasi dengan pemberian zink ini dapat membantu proses metabolisme dan membantu kerja enzim di dalam tubuh salah satunya akan meningkatkan fungsi enzim dalam tubuh. Jika fungsi enzim dalam tubuh berlangsung dengan baik, maka asupan makanan yang masuk ke dalam tubuh dapat mudah diserap dan berfungsi optimal dalam membantu proses pertumbuhan ${ }^{[4]}$.

Pemberian modisco bagi anak efektif, lantaran porsi makanan atau minuman relatif kecil namun mengandung kalori dan protein tinggi, mudah dicerna karena terdiri dari lemak nabati dan lemak berantai sedang, merupakan cara alternatif bagi anak yang tidak suka susu, juga dapat meningkatkan BB secara cepat, yaitu 30-100 gram per hari ${ }^{[5]}$.
Diharapkan dengan pemberian kombinasi modisco dan sirup zink ini dapat mengatasi masalah gizi baik dan buruk dengan cepat karena modisco mudah dicerna oleh tubuh dan sirup zink dapat mempercepat kerja metabolisme tubuh $^{[5]}$.

Dari hasil Pemantauan Status Gizi Balita (PSG) yang dilaksanakan setiap tahun di Kabupaten Malang menunjukkan persentase gizi buruk dan gizi kurang 2005-2007 mengalami peningkatandan tahun 2007- 2009 mengalami penurunan meskipun penurunannya relatif kecil sedangkan tahun 2008-2012 prevalensi kasus gizi kurang mengalami penurunan dari $13,01 \%$ tahun 2007 menjadi $6,14 \%$ tahun 2012 dan prevalensi gizi buruk dari $1,01 \%$ tahun 2008 menjadi 3,40\% tahun 2010, sedangkan tahun 2012 prevalensi gizi buruk turun sebesar $0.84 \%$. Hasil Riset Kesehatan Dasar (Riskesdas) tahun 2007 di Jawa Timur prevalensi balita gizi buruk sebesar 4,8\% dan balita gizi kurang sebesar $12,6 \%$ dan di Kabupaten Malang prevalensi balita gizi buruk sebesar $3,1 \%$ dan balita gizi kurang sebesar 9,4\%. Hasil PSG tahun 2011 bila dibandingkan dengan hasil Riskesdas tahun 2007, maka prevalensi gizi buruk dan prevalensi gizi kurang hasil PSG lebih rendah daripada hasil Riskesdas.

\section{Metode Penelitian}

Desain Penelitian dalam penelitian ini adalah quasy eksperimen dengan pendekatanpre and post test design with control group. Waktu pemberian perlakuanadalah selama 2 bulan. Pemberian perlakuan sebanyak tiga kali dalam satu minggu hingga dua bulan dengan dosis sirup zink sebanyak 2,5 mg. Populasi dalam penelitian ini adalah balita dengan KEP sedang dan berat yang diberi sirup zink sebanyak 20 orang. Sampel yang digunakan dalam penelitian ini adalah semua balita yang mengalami KEP sedang dan berat. Pada penelitian ini dibagi menjadi 2 kelompok yaitu kelompok pertama yang diberikan modisco dan kelompok kedua 
yang diberi perlakuan kombinasi modisco dan zink

Teknik yang digunakan dalam penelitian ini adalah total population sampling dengan cara mengambil semua populasi sebagai sampel. Teknik analisa data digunakan untuk mengetahui ada tidaknya pengaruh pemberian sirup zink terhadap perubahan berat badan pada balita dengan KEP sedang dan berat.

Analisis bivariat dilakukan dengan t-test terlebih dahulu sebelum mendapatkan hasil untuk nilai Eta squared sebagai nilai efektivitas pemberian sirup zink terhadap perubahan berat badan. Nilai standar untuk perhitungan Eta Squared jika nilai Eta Squared 0,01 - 0,05=efek kecil, $0,06-0,13=$ efek sedang dan $0,14-$ 1=efek besar. Eta Squared didapatkan setelah $\mathrm{t}$ hitung didapatkan melalui independent $t$-test

Etika Penelitian ini meliputi informed consent (lembar persetujuan) yang diberikan kepada ibu yang memiliki balita, anonymity dengan hanya memberikan initial pada responden, serta bersifat rahasia

\section{Hasil dan Pembahasan}

Dalam penelitian ini, hasil penelitian dibagi menjadi dua data yaitu data umum dan data khusus. Data umum yang disajikan meliputi umur ibu dan tingkat pendidikan ibu sedangkan data khusus meliputi berat badan sebelum dan sesudah diberi perlakuan selama 2 bulan.

Tabel 1 Distribusi Frekuensi Umur Ibu

\begin{tabular}{ccccc}
\hline \multirow{2}{*}{ Umur Ibu } & \multicolumn{2}{l}{ Kelompok } & \multicolumn{2}{l}{ Kelompok } \\
& $\mathbf{1}$ & \multicolumn{2}{c}{$\mathbf{2}$} \\
\cline { 2 - 5 } & $\mathbf{f}$ & $\mathbf{\%}$ & $\mathbf{f}$ & $\mathbf{\%}$ \\
\hline$<17$ tahun & 4 & 40 & 5 & 50 \\
\hline $17-35$ tahun & 3 & 30 & 3 & 30 \\
\hline$>35$ tahun & 3 & 30 & 2 & 20 \\
\hline Total & 10 & 100 & 10 & 100 \\
\hline
\end{tabular}

Tabel 1 menunjukkan pada kelompok 1 (perlakuan modisco) hasil bahwa hampir setengahnya (40\%) umur ibu yaitu < 17 tahun sebanyak 4 orang sedangkan kelompok 2 (kombinasi modisco dan zink) hasil bahwa setengahnya (50\%) umur ibu yaitu < 17 tahun sebanyak 5 orang.

Tabel 2 Distribusi Frekuensi Pendidikan Ibu

\begin{tabular}{ccccc}
\hline \multirow{2}{*}{$\begin{array}{c}\text { Pendidikan } \\
\text { Ibu }\end{array}$} & \multicolumn{2}{l}{ Kelompok } & \multicolumn{2}{c}{ Kelompok } \\
& $\mathbf{1}$ & \multicolumn{2}{c}{$\mathbf{2}$} & \\
\cline { 2 - 5 } & $\mathbf{f}$ & $\mathbf{\%}$ & $\mathbf{f}$ & $\mathbf{\%}$ \\
\hline SD & 6 & 60 & 7 & 70 \\
\hline SMP & 3 & 30 & 2 & 20 \\
\hline SMA & 1 & 10 & 1 & 10 \\
\hline PT & & & - & \\
\hline Total & 10 & 100 & 10 & 100 \\
\hline
\end{tabular}

Tabel 2 menunjukkan hasil bahwapada kelompok 1 (perlakuan modisco) dan kelompok 2 (kombinasi modisco sebagian besar sebanyak $60 \%$ dan $70 \%$ tingkat pendidikan ibu adalah SD

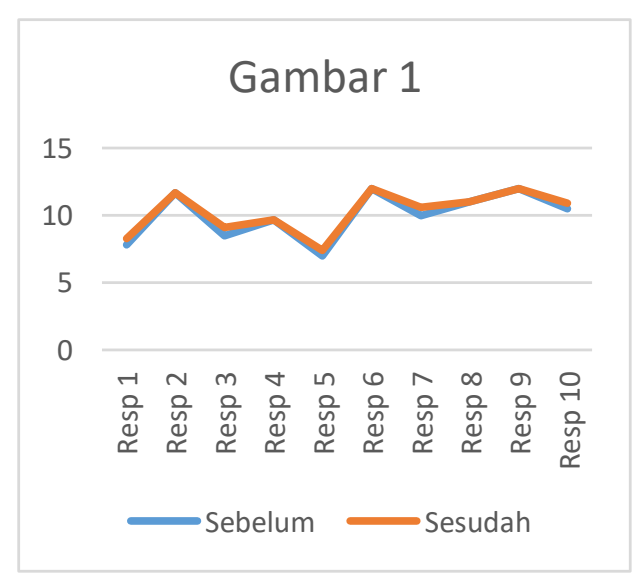

Gambar 1 Berat badan balita sebelum dan sesudah kelompok 1 (pemberian modisco)

Berdasarkan Gambar 1 menunujukkan bahwa terdapat perubahan berta badan pada balita dengan KEP sedang dan berat setelah diberi modisco selama 2 bulan 


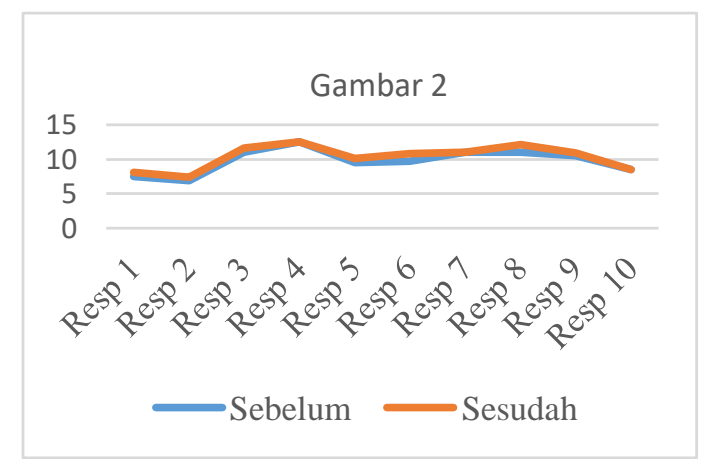

Gambar 2 Berat badan balita sebelum dan sesudah kelompok 2 (pemberian kombinasi sirup zink dan modisco)

Berdasarkan Gambar 2
menunujukkan bahwa terdapat
perubahan berta badan pada balita
dengan KEP sedang dan berat setelah
diberi sirup zink dan modiscoselama 2
bulan

Tabel 3 Hasil Observasi Perubahan Berat Badan Setelah diberi Pemberian Sirup Zink Selama 2 bulan

\begin{tabular}{ccccc}
\hline \multirow{2}{*}{$\begin{array}{c}\text { Perubahan } \\
\text { Berat Badan }\end{array}$} & \multicolumn{1}{l}{ Kelompok } & \multicolumn{2}{l}{ Kelompok } \\
\cline { 2 - 5 } & $\mathbf{f}$ & $\boldsymbol{2}$ & $\mathbf{f}$ & $\mathbf{\%}$ \\
\hline Naik & 5 & 50 & 7 & 70 \\
\hline Tetap & 5 & 50 & 3 & 30 \\
\hline Turun & 0 & 0 & 0 & 0 \\
\hline Total & 10 & 100 & 10 & 100 \\
\hline
\end{tabular}

Berdasarkan hasil penelitian setelah pemberian kombinasi sirup zink dan modisco selama 2 bulan pada balita dengan KEP sedang dan berat sebagian besar mengalami kenaikan berat badan sebanyak 7 orang $(70 \%)$ dan berat sedangkan sebagian kecil balita yang berat badannya tetap sebanyak 3 (30\%) sedangkan pada kelompok kontrol yaitu hanya pemberian modisco setengahnya mengalami kenaikan berat badan sebanyak 5 orang $(50 \%)$ dan berat sedangkan setengahnya balita yang berat badannya tetap sebanyak 5 (50\%).

Berdasarkan Uji Statistik menggunakan $\mathrm{T}$-test didapatkan $\mathrm{p}=$ 0,034 sehingga $p<0,05$ yang menunjukkan Ha diterima artinya ada perbedaan pemberian sirup zink dan modisco terhadap perubahan berat badan balita pada balita dengan KEP sedang dan berat dan setelah. Eta Squared yang didapatkan 0,28 disimpulkan jika terdapat efektivitas yang besar kombinasi pemberian sirup zink dan modisco terhadap peningkatan berat badan balita.

Setelah pemberian kombinasi sirup zink dan modisco selama 2 bulan pada balita dengan KEP sedang dan berat sebagian besar mengalami kenaikan berat badan sebanyak 7 orang (70\%) dan berat sedangkan sebagian kecil balita yang berat badannya tetap sebanyak 3 (30\%) sedangkan pada kelompok kontrol yaitu hanya pemberian modisco setengahnya mengalami kenaikan berat badan sebanyak 5 orang $(50 \%)$ dan berat sedangkan setengahnya balita yang berat badannya tetap sebanyak 5 (50\%).

Berdasarkan Uji Statistik menggunakan $\mathrm{T}$-test didapatkan $\mathrm{p}=$ 0,034 sehingga $\mathrm{p}<0,05$ yang menunjukkan Ha diterima artinya ada perbedaan pemberian sirup zink dan modisco terhadap perubahan berat badan balita pada balita dengan KEP sedang dan berat dan setelah. Eta Squared yang didapatkan 0,28 disimpulkan jika terdapat efektivitas yang besar kombinasi pemberian sirup zink dan modisco terhadap peningkatan berat badan balita.

Hasil penelitian ini sesuai dengan teori yang menyatakan bahwa zink ini dapat membantu proses metabolisme dan membantu kerja enzim di dalam tubuh salah satunya akan meningkatkan fungsi enzim dalam tubuh. Jika fungsi enzim dalam tubuh berlangsung dengan baik, maka asupan makanan yang masuk ke dalam tubuh dapat mudah diserap dan berfungsi optimal dalam membantu proses pertumbuhan ${ }^{[6]}$.

Selain itu zink sebagai mineral mikro yang terdapat dalam jumlah sangat kecil di dalam tubuh memegang peranan penting dalam banyak fungsi tubuh. Zink sebagai bagian dari enzim atau sebagai kofaktor pada kegiatan lebih dari dua ratus enzim, zink berperan 
dalam berbagai aspek metabolism, seperti reaksi-reaksi yang berkaitan dengan sintesis dan degradasi karbohidrat, protein, lipida dan asam nukleat. Sebagai bagian dari enzim peptidase karboksil yang terdapat di dalam cairan pancreas, zink berperan dalam pencernaan protein $^{[7]}$.

Pemberian sirup zink pada penelitian ini dapat membantu proses metabolism dan membantu kerja enzimenzim di dalam tubuh sehingga salah satunya akan meningkatkan fungsi enzim dalam tubuh sehingga dengan fungsi enzim dalam tubuh berlangsung dengan baik, maka asupan makanan yang masuk ke dalam tubuh dapat mudah diserap dan berfungsi optimal dalam membantu proses pertumbuhan. Hal ini tampak pada perubahan berat badan anak yang menderita gangguan $\operatorname{gizi}^{[8]}$.

Manfaat modisco yang paling utama adalah untuk mengatasi gizi buruk pada anak dengan cepat dan mudah. Karena modisco mempunyai kandungan kalori yang tinggi serta mudah dicerna oleh anak. Selain itu bahan-bahan pembuatan modisco mudah untuk di dapat dengan harga yang terjangkau walaupun oleh kalangan menengah ke bawah ${ }^{[9]}$.

Pemberian modisco bagi anak efektif, lantaran porsi makanan atau minuman relatif kecil namun mengandung kalori dan protein tinggi, mudah dicerna karena terdiri dari lemak nabati dan lemak berantai sedang, merupakan cara alternatif bagi anak yang tidak suka susu, juga dapat meningkatkan BB secara cepat, yaitu 30-100 gram per hari ${ }^{[5]}$.

Hal ini sesuai dengan penelitian sebelumnya tahun 2009 menunjukkan bahwa anak dengan riwayat suplementasi zink+PMT saat usia 6 hingga 7 tahun memiliki pertambahan berat badan yang lebih baik dibanding anak tanpa riwayat keduanya yaitu 14.43 $\mathrm{kg}^{[10]}$.

Beberapa faktor yang berpengaruh terhadap asupan makanan antara lain kebiasaan makanan, rasa suka dan tidak suka terhadap makanan tertentu akan terbawa sampai dewasa dan seringkali sulit diperbaiki, termasuk juga lingkungan keluarga, media massa, teman sebaya dan penyakit. Problema makan pada anak dapat berakibat buruk bagi tumbuh kembang anak. Sedikitnya makanan yang masuk ke dalam perut anak dapat menjadi indikasi bahwa anak mempunyai peluang besar untuk menderita kurang gizi ${ }^{[11]}$.

Jika dikaitkan dengan pendidikan ibu pada penelitian ini sebagian besar berpendidikan SD dan sebagian besar umur ibu yaitu $<17$ tahun akan berpengaruh terhadap masalah gizi pada balita karena dengan yang berpendidikan rendah bagi seorang ibu belum mengerti tentang arti makanan bergizi bagi pertumbuhan balitanya. Hal ini diperparah lagi dengan adanya balita yang tidak suka makan tetap dibiarkan saja sehingga menyebabkan asupan makanan yang masuk ke dalam tubuh menjadi berkurang. Akibatnya akan memperburuk kejadian gizi kurang pada balita yaitu perubahan berat badan balita menjadi tetap bahkan turun.

\section{Kesimpulan}

Berdasarkan hasil penelitian setelah pemberian kombinasi sirup zink dan modisco selama 2 bulan pada balita dengan KEP sedang dan berat sebagian besar mengalami kenaikan berat badan sebanyak 7 orang $(70 \%)$ dan berat sedangkan sebagian kecil balita yang berat badannya tetap sebanyak 3 (30\%) sedangkan pada kelompok kontrol yaitu hanya pemberian modisco setengahnya mengalami kenaikan berat badan sebanyak 5 orang $(50 \%)$ dan berat sedangkan setengahnya balita yang berat badannya tetap sebanyak 5 (50\%).

Berdasarkan Uji Statistik menggunakan $\mathrm{T}$-test didapatkan $\mathrm{p}=$ 0,034 sehingga $\mathrm{p}<0,05$ yang menunjukkan Ha diterima artinya ada perbedaan pemberian sirup zink dan modisco terhadap perubahan berat badan balita pada balita dengan KEP sedang dan berat dan setelah. Eta Squared yang 
didapatkan 0,28 disimpulkan jika terdapat efektivitas yang besar dengan pemberian kombinasi sirup zink dan modisco terhadap peningkatan berat badan balita pada balita dengan KEP

\section{Ucapan Terima Kasih}

Dengan terselesaikannya penelitian ini, maka penulis mengucapkan terima kasih kepada:

1. Kemenristekdikti, BPPM/SPK/03/11/2018, 2018 atas dana hibah

2. Letkol Ckm Arief Effendie S, MPH, S.Kep.Ners, SH, MM selaku direktur Poltekkes RS dr Soepraoen

3. drg. Anitarini selaku Kepala UPTD Puskesmas Jabung yang telah memberikan ijin penelitian

4. Laila Qodariyah, Amd. Gz yang telah membantu selama penelitian serta seluruh bidan desa wilayah kerja puskesmas jabung

\section{Daftar Pustaka}

[1]. Almatsier, Sunita. Prinsip Dasar Ilmu Gizi. Jakarta . PT Gramedia Pustaka Utama. 2004.

[2]. Hadi, Hamam. Sepertiga Anak Usia Sekolah Di Indonesia Alami Stunted. Yogyakarta: Universitas Gajah Mada. 2010

[3]. Krisnansari, Diah. Nutrisi dan Gizi Buruk. Mandala of Health, Volume4, Nomor 1, Januari 2010. Purwokerto: Fakultas Kedokteran dan Ilmu-ilmu Kesehatan Universitas Jenderal Soedirman. 2010.

[4]. Agustian L, Sembiring T, \& Ariani. Peran Zinkum Terhadap Pertumbuhan Anak. Sari Pediatri, Volume 11, Nomor 4, Halaman 244-249, Desember 2009. Departemen Ilmu Kesehatan Anak Fakultas Kedokteran Universitas Sumatera Utara.2009

[5]. Jamaluddin. Efek Pemberian Makanan Tambahan dan Zink Pada Ibu Hamil Kurang Energi Terhadap Status Pertumbuhan Tinggi Badan Anak Usia 6 Tahun di Kabupaten Takalar. Makassar : UNHAS. 2008

[6]. Masayuki K \& Nishi Y. Growth and Mineral : Zinc. Online. Journal American Coll Nutr. 2006. 22(1).

[7]. Imelda T Angeles. Decreased Rate Of Stunting Among Anemic Indonesian Preschool Children Through Iron Supplementation. Am j clin nutr. 1993;58:339-42. 2003

[8]. Putri. Pengaruh Pemberian Zink Terhadap Morbiditas Anak Di Kabupaten Takalar. Makassar : UNHAS. 2009

[9]. Mursalim, Juffrie, \& Mulyani. Pemberian Fortifikasi MultiMikronutrien Berpengaruh Terhadap Pertumbuhan Balita Keluarga Miskin. Jurnal Gizi Klinik Indonesia. 2011. 8(2).

[10]. Marhaeni. Perilaku Keluarga dalam Pemenuhan Gizi Balita di Wilayah Puskesmas Mangarabombang Kabupaten Takalar Tahun 2010. Jurnal Media Kebidanan Poltekes Makassar. 2010. 2(2).

[11].Lawrence J Whalley, et al. Cognitive Aging, Childhood Intelegence, And The Use Of Food Supplements:Possible Involvement Of N_3 Fatty Acid1-3. Am J clin Nutr. 2004;80:16-7. 